\title{
IODP Expedition 310 Reconstructs Sea Level, Climatic, and Environmental Changes in the South Pacific during the Last Deglaciation
}

\author{
by Gilbert F. Camoin, Yasufumi Iryu, Dave B. McInroy and \\ the IODP Expedition 310 Scientists
}

\section{Introduction and Goals}

The timing and course of the last deglaciation (19,0006,000 years BP) are essential components for understanding the dynamics of large ice sheets (Lindstrom and MacAyeal, 1993) and their effects on Earth's isostasy (Nakada and Lambeck, 1989; Lambeck, 1993; Peltier, 1994), as well as the complex relationship between freshwater fluxes to the ocean, thermohaline circulation, and, hence, global climate during the Late Pleistocene and the Holocene. Moreover, the last deglaciation is generally seen as a possible analogue for the environmental changes and increased sea level that Earth may experience because of the greenhouse effect, related thermal expansion of oceans, and the melting of polar ice sheets.

Corals are excellent sea level indicators and can be accurately dated; therefore, studying them helps in the determination of the timing of deglaciation events and the understanding of the mechanisms driving the glacial-interglacial cycles. Coral reefs are also sensitive recorders of past climatic and environmental changes. The skeletal geochemistry of annually-banded massive corals can provide a record of sea surface temperatures (SSTs) and salinities (SSSs). Because the amplitude of the last deglacial sea level rise was at least 120 m (Barbados: Fairbanks, 1989; Bonaparte Basin: Yokoyama et al., 2001; and review in Lambeck et al., 2002), the relevant reef and sediment archives are mostly found on modern fore-reef slopes where they can be investigated by dredging, submersible sampling, and coring. However, the scarcity of such cores and related data hinders our ability to unravel the rate and timing of the last deglacial sea level rise and prevents us from understanding the role of the Pacific Ocean as a climate modulator during the course of postglacial climate change.
Sea level changes and reef development during the last deglaciation: The magnitude and rates of eustatic changes constrain the volumes of ice that accumulated on the continents during the last glacial period, including the Last Glacial Maximum (LGM), and provide direct evidence of the progress of melting of large ice sheets during the last deglaciation.

So far, only three deglaciation curves based on coral reef records have been accurately dated for times reaching the Pleistocene-Holocene boundary-in Barbados between 19,000 and 8,000 yr BP (Fairbanks, 1989; Bard et al., 1990); in Papua New Guinea between 13,000 and 6,000 yr BP (Chappell and Polach, 1991; Edwards et al., 1993), and in Tahiti between 13,850 and 3,000 yr BP (Bard et al., 1996). Of these, the only coral reef record that encompasses the whole last deglaciation is from the Barbados, where it was suggested that this period was characterized by two brief intervals of accelerated melting (meltwater pulses MWP-1A and MWP-1B at $\sim 14,000$ and 11,300 yr BP, respectively) superimposed on a smooth and continuous rise of sea level with no reversals (Fairbanks, 1989; Bard et al., 1990). These events would correspond to massive inputs of continental ice to the oceans (i.e., $~ 50-40 \mathrm{~mm} \mathrm{y}^{-1}$, roughly equivalent to an annual discharge of $16,000 \mathrm{~km}^{3}$ for MWP-1A), and they are thought to have induced reef drowning events (Blanchon and Shaw, 1995). However, the abrupt and significant environmental changes that accompanied the deglacial rise in sea level have barely been investigated, leaving the accurate reconstruction of the event obscured.

The timing, the amplitude, and even the realities of those periods of accelerated sea level rise have been actively debated (Bard et al., 1996; Okuno and Nakada, 1999; Lambeck et al., 2002; Clark et al., 2004). Uncertainties con-

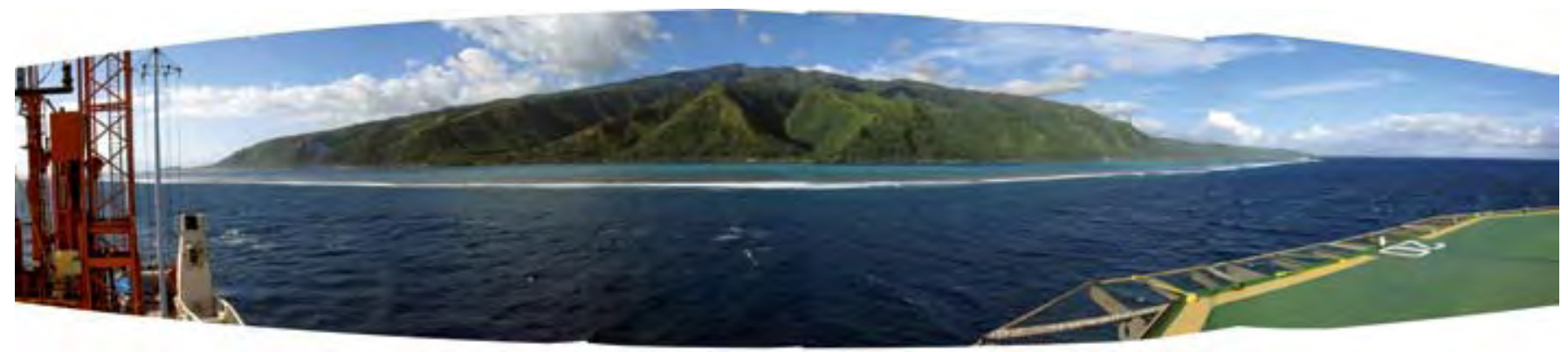

Figure 1. View of Tahiti from the DP Hunter during IODP Expedition 310. The picture was taken in the Maraa area in Southern Tahiti while stationed at Site M0007. Photo by Rolf Warthmann. 
cerning the general pattern of sea level rise during this time period remain because the apparent sea level record may not be free of tectonic or isostatic complications. The Barbados sea level curve was derived from three separate drowned reefs, and each of these segments is offset from the next. Moreover, these offsets constitute the two rapid meltwater surges; however, because these sites are located close to subduction zones, sea level records derived from them may be impacted by unknown tectonic movements. It is therefore preferable to obtain sea level data from tectonically stable regions truly distant from the former ice sheets ("far-field" sites), sites that are minimally affected by isostatic rebound in relation to changes in ice loading of the lithosphere (Mix et al., 2001; Clark and Mix, 2002).

Tahiti is a volcanic island characterized by slow and regular subsidence rates ( $0.25 \mathrm{~mm} \mathrm{yr}^{-1}$; Bard et al., 1996) and located at a considerable distance from the major former ice sheets. Therefore, it provides an ideal setting to reconstruct the deglacial rise in sea level and to constrain short-term events that are thought to have punctuated the period between the LGM and the present days.

Climatic variability during the last deglaciation: The tropical Pacific Ocean is known to play an important role in driving and modulating global climate variability and change on a wide range of timescales (Bjerknes, 1969; Pickard and Emery, 1990). Furthermore, climate modeling of global warming implies that the tropical Pacific is pivotal in modulating the timing, regional expression, and magnitude of climate change.

The tropical Pacific may have played an important role in glacial-interglacial timescale climate change, but currently there is debate over exactly what this role was. Additional information is therefore required for a better knowledge on climatic conditions in tropical regions during the last deglaciation, including the changes in the seasonal cycle (amplitude and structure) that are likely to yield important insights into the mechanisms and drivers of climate variability and change.

\section{Scientific objectives of the expedition were:}

A) To establish the course of postglacial sea level rise during the last deglaciation in order to 1) establish the minimum sea level during the LGM; 2) assess the validity, timing, and amplitude of meltwater pulses and thereby identify the exact sources of the ice responsible for these rapid sea level steps; 3 ) prove or disprove saw-tooth pattern of sea level rise; and 4) test predictions based on different ice and rheological models.

B) To define variations in SSTs and SSSs during the last deglaciation when solar insolation, sea level, and atmospheric $\mathrm{CO}_{2}$ levels were different from today. The objectives are to 1) reconstruct interannual-decadal climate variability and seasonality (amplitude and structure) in the South Pacific; 2) reconstruct variability and change in interannual including

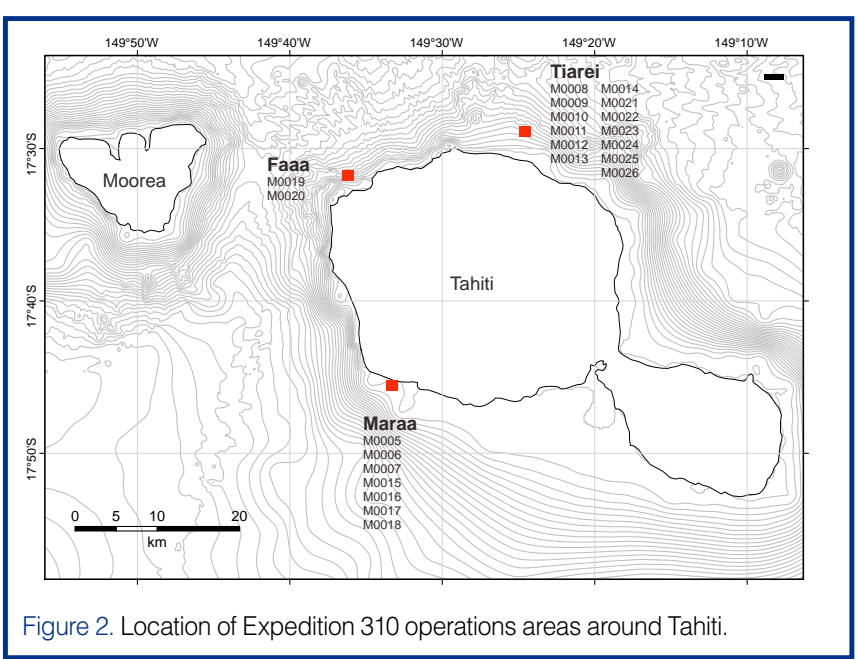

El Nino Southern Oscillation (ENSO) and decadal-interdecadal including Pacific Decadal Oscillation (PDO)/ Interdecadal Pacific Oscillation (IPO) variability; 3) compare the global variation and relative timing of postglacial warming between the tropical Pacific and the mid- and high-, northern and southern latitudes; and 4) determine major changes in tropical sea surface salinity.

C) To analyze the impact of sea level and environmental changes on reef development during the last deglaciation, with a special emphasis on the comprehensive reconstruction of environmental changes (e.g., nutrient concentrations, variations in $\mathrm{pH}$ and alkalinity, paleoproductivity, terrigenous and freshwater fluxes), the evolution of the geometry, biological composition, and growth mode of reef frameworks.

D) To investigate the geomicrobiology processes on the Tahiti fore-reef slopes to study potential modern counterparts of the microbialites that characterize the last deglacial reef sequence drilled in Papeete (Camoin and Montaggioni, 1994; Camoin et al., 1999). The objectives are to 1) identify the microbial communities that are involved in their formation and 2) to have a better understanding of the environmental significance of those microbial fabrics.

\section{Drilling Sites and Operational Strategy}

At Tahiti, recovery of the last deglacial reef sequence required drilling successive reef terraces of various lateral extent that occur at various depths $(100,90,60$, and 40-50 m) seaward of the living barrier reef (Camoin et al., 2003). Preliminary sedimentological and chronological results on the dredged samples have confirmed the significance of these features as unique archives of abrupt global sea level rise and climate change (Camoin et al., 2006). Based on the results of previous drillings on the Papeete reef (Bard et al., 1996; Montaggioni et al., 1997; Camoin et al., 1999 ; Cabioch et al., 1999a) and of the SISMITA cruise (Camoin et al., 2003), we drilled a transect of holes in three areas around Tahiti-offshore Faaa, Tiarei, and Maraa (Figs. 1 and 2). The final and exact locations of the drill holes was determined during the drilling cruise by mapping the nature and morphology of the seafloor with a through-pipe underwater 


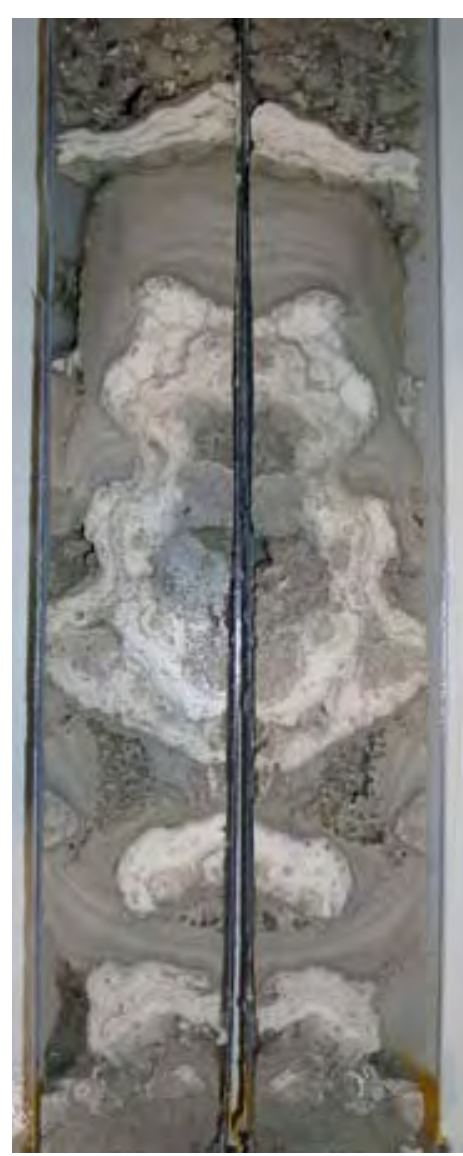

Figure 3. Core displaying coralgal frameworks heavily encrusted with micro bialites (laminated fabrics overlain by dendritic growth forms)

(Unit I) and an older Pleistocene sequence (Unit II). Those two major units have been divided into subunits based on coral assemblages and internal structure.

The set of deployed borehole geophysical instruments was constrained by the scientific objectives and the geological setting of the expedition. A suite of downhole geophysical methods was chosen to obtain high resolution images of the borehole wall (OBI40 and ABI40 televiewer tools; Fig. 4), to characterize the fluid nature in the borehole (IDRONAUT tool), to measure borehole size (CAL tool), and to measure or derive petrophysical and geochemical properties of the reef units such as porosity, electrical resistivity (DIL 45 tool), acoustic velocities (SONIC tool), and natural gamma radioactivity (ASGR tool). A total of ten boreholes were prepared for downhole geophysical measurements, which were performed under open borehole conditions (no casing) with the exception of a few spectral gamma ray logs. Nearly complete downhole coverage of the postglacial reef sequence has been obtained from $72 \mathrm{mbsl}$ to $122 \mathrm{mbsl}$ and from $41.65 \mathrm{mbsl}$ to $102 \mathrm{mbsl}$ at the Tiarei sites and the Maraa sites, respectively. Partial downhole coverage of the underlying older Pleistocene carbonate sequence has been acquired at both sites.

Samples from Tahiti drill cores were analyzed for evidence of microbial activity, possibly related to the formation of microbialites. Onboard measurements have shown a certain degree of microbial activity directly attached to rock surfaces; cultivation and microscopic observations were also carried out onboard. According to the adenosine triphosphate (ATP) activity measurements along the drill cores, the uppermost part (0-4 mbsf of the Tahiti reef slopes) is the most active zone. Pure microbiological activity was only observed in reef cavities where prokaryotic biofilms have appropriate conditions to develop. Northwestern Faaa Hole M0020A and southwestern Maraa Holes M0005C, M0007B, $\mathrm{M} 0007 \mathrm{C}, \mathrm{M} 0015 \mathrm{~B}$, and M0018A were more active than the northeastern Tiarei sites where usually no living biofilm could be detected in cavities along the cores.

\section{Last Deglacial Sequence}

Composition: The last deglacial sequence is mostly composed of coralgal frameworks heavily encrusted with microbialites (Fig. 3), locally associated or interlayered with skeletal limestone and/or loose skeletal sediments (rubble, sand, and silt) rich in fragments of corals, coralline and green (Halimeda) algae, and, to a lesser extent, bryozoans, echinoids, mollusks, and foraminifers (mostly Amphistegina and Heterostegina). The amounts of volcaniclastic sediments (e.g., silt- to cobble-sized lithic volcanic clasts, mineral fragments, clays) are highly variable, from mere sand and silt impurities in the carbonate rock units to minor components $(<50$ vol- $\%)$ in carbonate sand units to major components (>50 vol-\%) in sand/silt (or sandstone/siltstone) interbedded with carbonate beds. The last deglacial sequence at Tiarei has a greater volcaniclastic component than the ones at Maraa and Faaa; this difference is observed on digital image scans and quantified by diffuse color reflectance spectrophotometry and magnetic susceptibility core logs.

Corals are well preserved, forming seven distinctive coral assemblages characterized by various morphologies (branching, robust branching, massive, tabular, foliaceous, and encrusting) that determine distinctive framework internal structure. Several coral assemblages are intergradational vertically and laterally. Robust branching (e.g., Pocillopora and Acropora) and, to a lesser extent, tabular (e.g., Acropora) corals are usually thickly encrusted with nongeniculate coralline algae and microbialites to form dense and compact frameworks; vermetid gastropods and serpulids are locally associated with coralline algae. Foliaceous and encrusting coral colonies (e.g., Montipora, Porites, Pavona, Leptastrea, Psammocora, Astreopora, agariciids and faviids) are thinly coated with coralline algae and microbialites to form loose frameworks. Large primary cavities in coralgal frameworks are open or partially filled with skeletal sands and gravels locally mixed with volcanic elements. The open framework and centimeter- to decimeter-sized pores result in a highly variable system in which physical properties change on a centimeter scale and may range from low porosity, high density, and velocity to $100 \%$ open pore space. 
Abundant microbialites represent the major structural and volumetric component of the last deglacial reef sequence (Figs. 3 and 4). The presence of microbialites at all depths in the sequence indicates that they formed in various parts of the reef tracts (Camoin et al., 2007). They developed within the primary cavities of the reef framework, where they generally overlie coralline algal crusts to form dark gray massive crusts as thick as $20 \mathrm{~cm}$; they also develop in bioerosion cavities. Microbialites correspond to a late stage of encrustation of the dead parts of coral colonies, or more commonly, of related encrusting organisms (coralline algae and crustose foraminifers), implying that some time elapsed prior to the formation of the microbialites and that there was generally no direct inter-community competition for space between coralgal and microbial communities. This is also reflected by the age differences between corals, encrusting organisms, and overlying microbialite crusts (Camoin et al., 2007). Microbialites generally comprise a suite of fabrics, including two end-members represented by laminated fabrics and thrombolitic to dendritic accretions; thrombolites usually represent the last stage of encrustation. The thickness and morphology of the microbial crusts are closely related to the morphology and size of the cavities in which they are developed. In bindstone formed by encrusting coral assemblages, microbialites are dominated by thrombolitic fabrics, whereas in frameworks made of branching and massive coral colonies, they are characterized by the development of compound crusts, up to $15 \mathrm{~cm}$ thick, formed by a succession of laminated and thrombolitic fabrics. Preliminary results obtained on lipid biomarkers imply that carbonate precipitation processes were related to the activity of heterotrophic bacteria and were in agreement with the stable isotope data (Heindel et al., 2007).

At all sites, the top of the last deglacial carbonate sequence is characterized by the widespread development of thin coralline algal crusts indicating deep water environments. Extensive bioerosion, dark yellow-reddish to brown staining (manganese and iron) of the rock surface, and hardgrounds are common within the top $2-3 \mathrm{~m}$ of the sequence.

Distribution of the last deglacial reef sequence: At all sites, the last deglacial sequence displays similar trends, although it displays specific characters in each area.

The Tiarei area is characterized by the occurrence of two successive ridges seaward of the living barrier reef (Camoin et al., 2003; Camoin et al., 2006). The outer ridge coincides with a marked break in slope, and its top is located at 90-100 mbsl, whereas the inner ridge is located on an extensive terrace, and its top occurs at $60 \mathrm{mbsl}$. On the outer ridge, the last deglacial sequence was recovered from $81.7 \mathrm{mbsl}$ to 122.12 mbsl at sites 9, 21, 24, 25 and 26; the thickest continuous sequence, $29.98 \mathrm{~m}$, was recovered from Holes M0021A and M0021B (Fig. 6). On the inner ridge, the last deglacial sequence (recovered from $68 \mathrm{mbsl}$ to $92-98 \mathrm{mbsl}$ at site 23 ) is $24-30 \mathrm{~m}$ thick. On both sides of the outer ridge (Holes

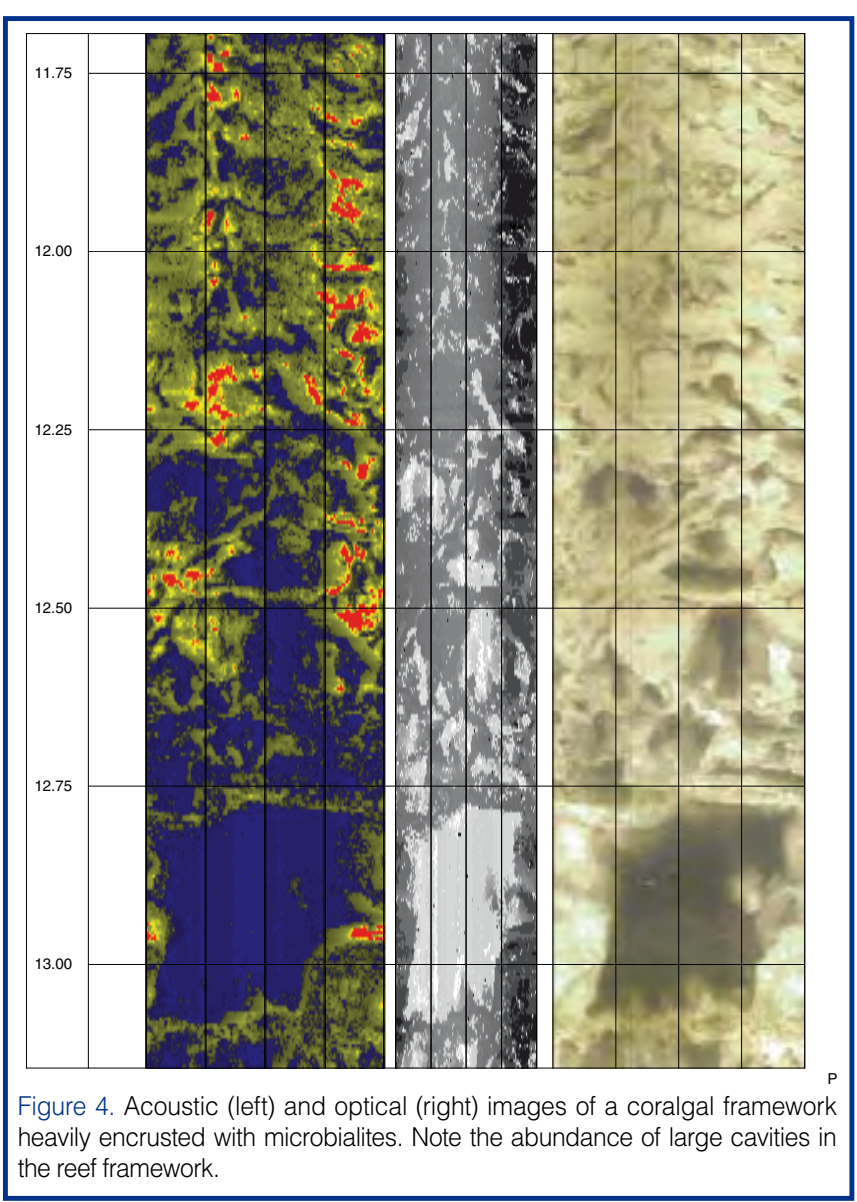

M0010A-M0014A), the last deglacial sequence (recovered from $78.85 \mathrm{mbsl}$ to $117.98 \mathrm{mbsl}$ ) includes reef units overlain by volcaniclastic sediments. At Hole M0008A, which is located on the flat area extending between the two ridges, the $38.7-\mathrm{m}$-thick sequence $(64.15-102.85 \mathrm{mbsl})$ consists only of volcaniclastic sediments.

Two transects were drilled in the Maraa area. The western transect includes Sites M0007, M0005, and M0006 (landward to oceanward) in water depths ranging from $41.65 \mathrm{~m}$ to $81.58 \mathrm{~m}$, and the thickness of the last deglacial sequence ranges from $33.22 \mathrm{~m}$ to $44.56 \mathrm{~m}$ at sites M0005 and M0007, respectively (Fig. 7). Sites M0017, M0015, M0018, and M0016 (landward to oceanward) in water depths ranging from 56.45 $\mathrm{m}$ to $81.8 \mathrm{~m}$ define the eastern transect; the thickness of the last deglacial sequence ranges from $35.44 \mathrm{~m}$ in Hole M0015A at $72.15 \mathrm{mbsl}$ to $39.05 \mathrm{~m}$ in Hole M0018A at $81.8 \mathrm{mbsl}$ (Fig. 8).

In the Faaa area, the last deglacial sequence is $62.5 \mathrm{~m}$ and $36.5 \mathrm{~m}$ thick at Sites M0019 (58.5 mbsl) and M0020 (83.3 mbsl), respectively.

Sea level issues: Coralgal assemblages identified in the Tahiti cores can be considered as reliable depth indicators for the reconstruction of sea level changes. Dominant species of coralline algal assemblages include Hydrolithon onkodes, $H$. reinboldii, Lithophyllum insipidum, L. pygmaeum, Neogoniolithon brassica-florida, and Mesophyllum erubescens; 


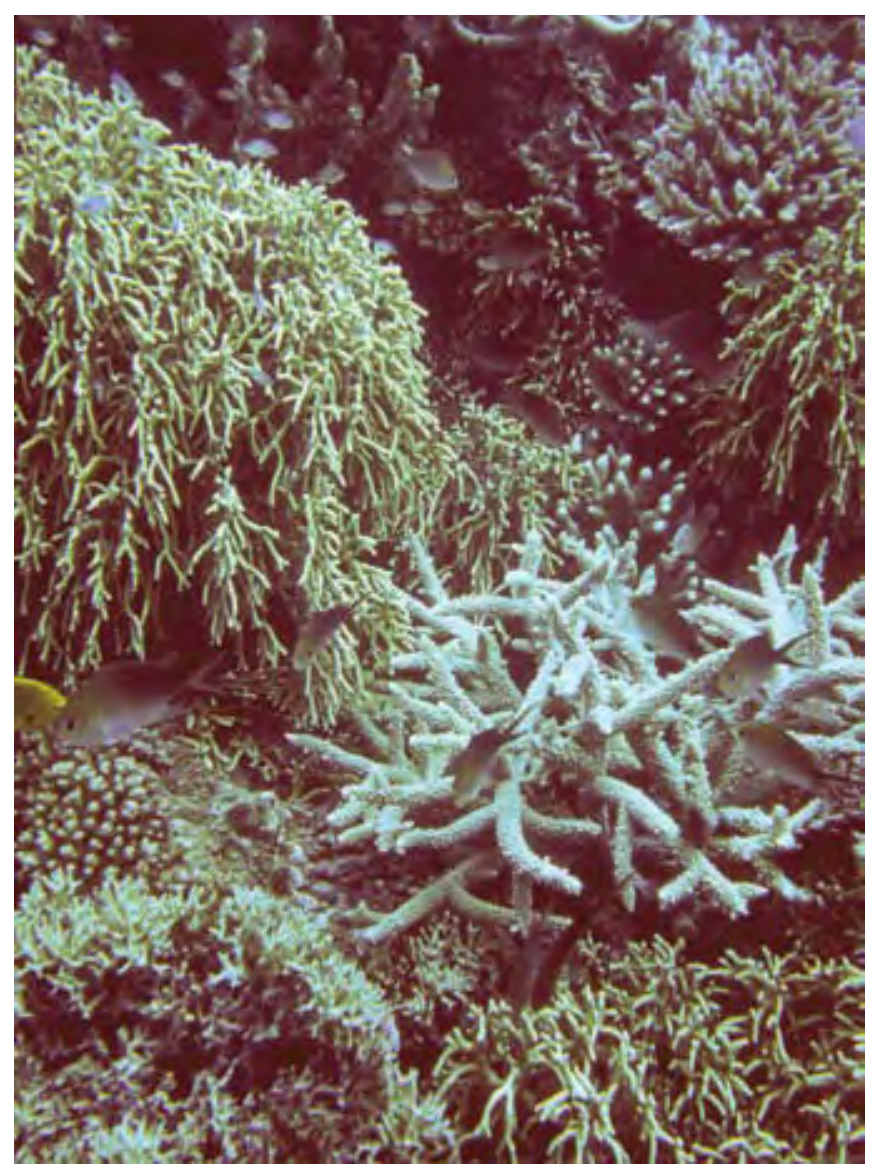

Figure 5. View of corals from the surface of the Tahiti reefs. Photo by Gilbert Camoin

they provide paleowater depth estimates based on their comparison with modern counterparts. Coral assemblages are dominated by Porites, Pocillopora, Acropora, and Montipora genera, which form distinctive assemblages that are indicative of a range of modern reef environments, from the upper to middle reef slope to deep reef slope (0-30 m deep; Sugihara et al., 2006), in agreement with earlier studies on Tahiti (Montaggioni et al., 1997; Camoin et al., 1999; Cabioch et al., 1999a) and other Indo-Pacific reef sites (Camoin et al., 1997, 2004; Montaggioni and Faure, 1997; Cabioch et al., 1999b; Sagawa et al., 2001).

Corals are well preserved, as the great majority of the specimens exhibit less than $1 \%$ calcite in their skeleton, indicating that they were not subjected to diagenetic alteration. Preliminary U-series dating results of selected corals indicate that the cored last deglacial sequence covers at least the 16,000-8,000 yrs BP time span, and suggest a non-monotonous sea level rise during that period. Additional data will be necessary to constrain it accurately (Deschamps et al., 2006, 2007). Tahiti is therefore the second region, after Barbados, where coral reef records encompass the MWP-1A and MWP$1 \mathrm{~B}$ events centered at $\sim 14,000 \mathrm{yr} \mathrm{BP}$ and 11,300 yr BP, respectively.

Paleomagnetic and rock magnetic testing are being carried out on all of the studied cores. The natural remanent magnetization (NRM) data obtained on microbialites show that directions have an average magnetic inclination that is very close to that expected at the site latitude from a simple dipole field. Moreover, the stratigraphic variations in inclination can be correlated between local sites, and they may also provide an independent chronostratigraphy for estimating the timing of microbialite growth within the reef primary cavities. Stratigraphic variations in several rock magnetic parameters can also be correlated between local sites, which may provide an independent record of environmental variability within the coral reef over time.

Reef development issues: At each drill site, the cored reef sequences are continuous, implying that there was no major break in reef development during the $16,000-8,000$ yrs BP time span, and thus raising the question of the occurrence of reef drowning events as described in the Barbados record (Blanchon and Shaw, 1995). This possibility suggests that environmental conditions in Tahiti were optimal for reef development, and no long-term environmental changes occurred during that period, although changes in coralgal assemblages may reflect variations in environmental parameters (e.g., water depth and energy, light conditions, terrigenous fluxes, nutrient concentrations, etc.). The deeper water facies that form the top of the last deglacial sequence occur gradually shallower towards the modern reefs along the drilled transects, thus indicating a general backstepping of the reef complex as a response to sea level rise during the last deglaciation.

Paleoclimate issues: About thirty meters of the reef cores consist of massive coral colonies, mostly of the genus Porites, and concern successive time windows covering most of the 16,000-8,000 yrs BP period. For paleoclimatic objectives, preliminary sub-seasonal records have been already obtained on selected time windows (Felis et al., 2007).

\section{Older Pleistocene Carbonate Sequence}

An older Pleistocene carbonate sequence has been recovered below the last deglacial sequence at most sites (Figs. 6, 7 , and 8 ). The contact between the last deglacial sequence and the older Pleistocene sequence is characterized by an irregular unconformity. The change in physical properties at this contact is sharp and abrupt—density, velocity, and magnetic susceptibility increase, and porosity decreases. The depth below present-day sea level of the top of the older Pleistocene sequence is highly variable, ranging from about $90 \mathrm{mbsl}$ on the inner ridge of Tiarei and proximal Maraa sites to $122 \mathrm{mbsl}$ on the outer ridge of Tiarei and distal Maraa sites. This variability indicates a rugged morphology of the Pleistocene carbonate substrate prior to the development of the last deglacial sequence.

Composition of the older Pleistocene carbonate sequence: The older Pleistocene carbonate sequence is mostly comprised of reef deposits and has been detailed in holes M0009D (Tiarei area; 122-147 mbsl; Fig. 6) and M0005D (Maraa area 
92-162 mbsl; Fig. 7). Three major distinctive lithological subunits are usually closely associated:

- well lithified skeletal packstone/grainstone to floatstone/ rudstone, rich in rhodoliths, and coral and algal fragments,

- well lithified coralgal frameworks exhibiting microbialite fabrics and associated with skeletal packstone/grainstone to floatstone, and

- rubbles and gravels primarily composed of coral clasts, limestone clasts, volcanic pebbles, and reworked coral colonies.

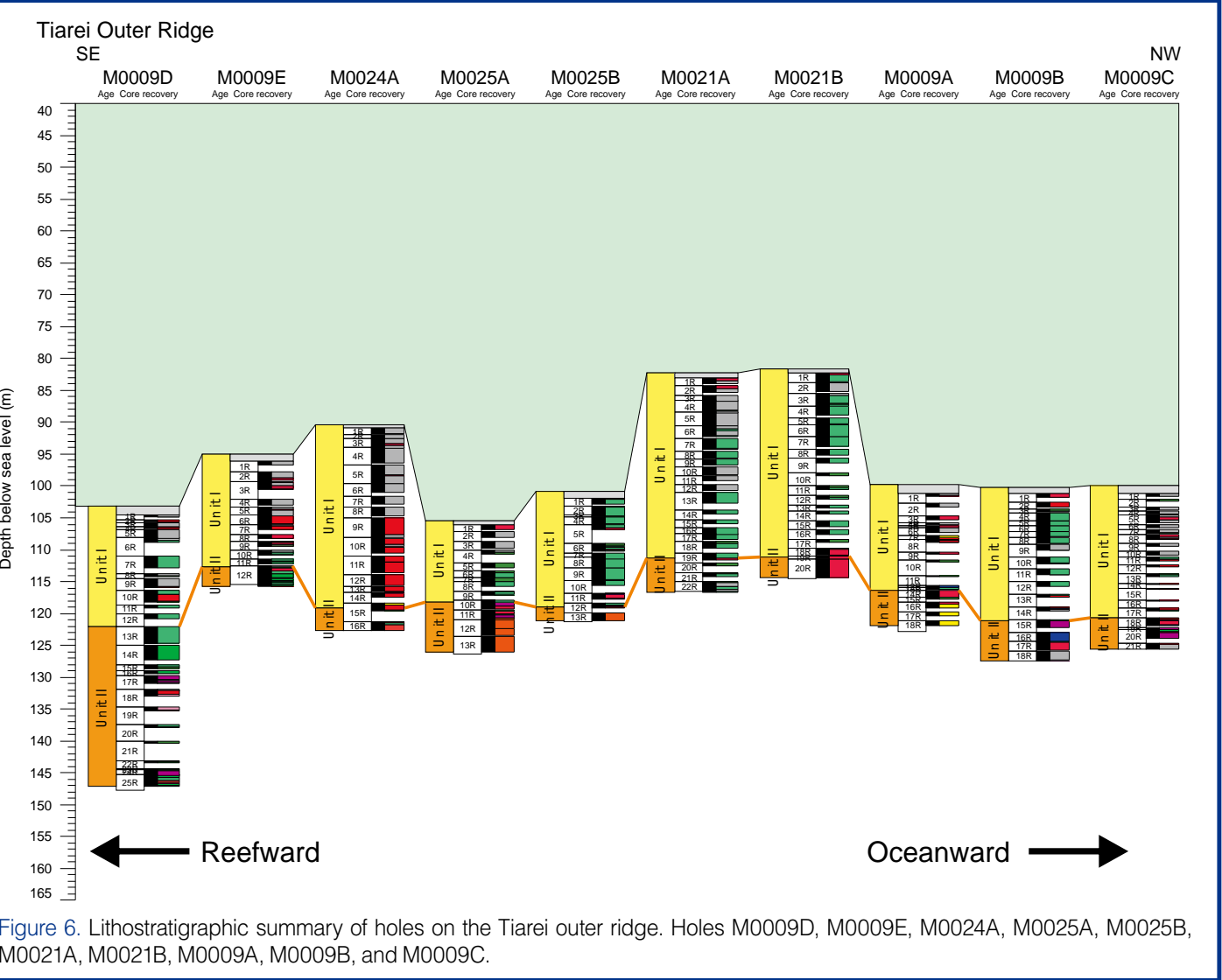

Ungraded unlithified volcaniclastic silt to sand, including scattered skeletal grains and sandy skeletal grainstone rich in volcanic grains, large coral clasts, and skeletal fragments, are clearly subordinate.

Several sedimentological features indicate that the older Pleistocene carbonate sequence has undergone several phases of diagenetic alteration resulting in tight, low-porosity, high-velocity limestones with much less variation in physical properties than observed for the last deglacial sequence. Several successive unconformities occur in the upper part of the older Pleistocene carbonate sequence and suggest that this sequence is composed of successive chronological units. Those unconformities are associated with several lines of evidence of subaerial diagenetic alteration, including the alteration of coral skeletons and skeletal grains, and the occurrence of abundant solution cavities rimmed with multiple generations of cement crusts and/or displaying several generations of sediment infillings and yellow and brown to red-brown staining. Local multiple bored and encrusted surfaces (hardgrounds) occur at the top of that sequence.

Chronology: The dating potential of the corals occurring in that sequence is generally limited by the amount of diagenesis they have suffered, but the preservation of some specimens was good enough to obtain reliable ages by U-series dating (Thomas et al., 2006).
Paleomagnetic studies provide chronological constraints on reef unit succession by identifying well dated paleointensity lows and geomagnetic excursions. The NRM is mostly carried by a mixture of titano-magnetite grains in the pseudosingle domain range. Based on the occurrence of excursional instabilities in two depth intervals, reef units have been attributed to highstand (isotopic stages 5 and 7) and lowstand reef units (isotopic stages 6 and 8) (Ménabréaz, 2007).

\section{Geomicrobiology of Modern Reef Slopes}

Biofilms recovered during the IODP Expedition 310 are diverse in structure and color. Additionally, finely laminated, 1-mm-diameter vertically upward growing columns referred to as endostromatolites were found within some reef cavities (McKenzie et al., 2007). Biofilms appear to have high diversity in macroscale observations, and they are equally diverse and heterogeneous in microscale resolution, as observed by scanning electron microscopy (SEM). In some samples, it was possible to define spherical assemblages of calcium carbonate minerals embedded in microbial exopolymeric substances (EPS).

Some evidence for heterotrophic metabolic activities is shown by exoenzyme measurements, which vary in the different biofilm samples. For instance, samples from holes M0020A (4.51 mbsf) and M0009D (3.64 mbsf) showed high phosphatase activity, suggesting the occurrence of a heterotrophic community that preferentially degrades organic- 


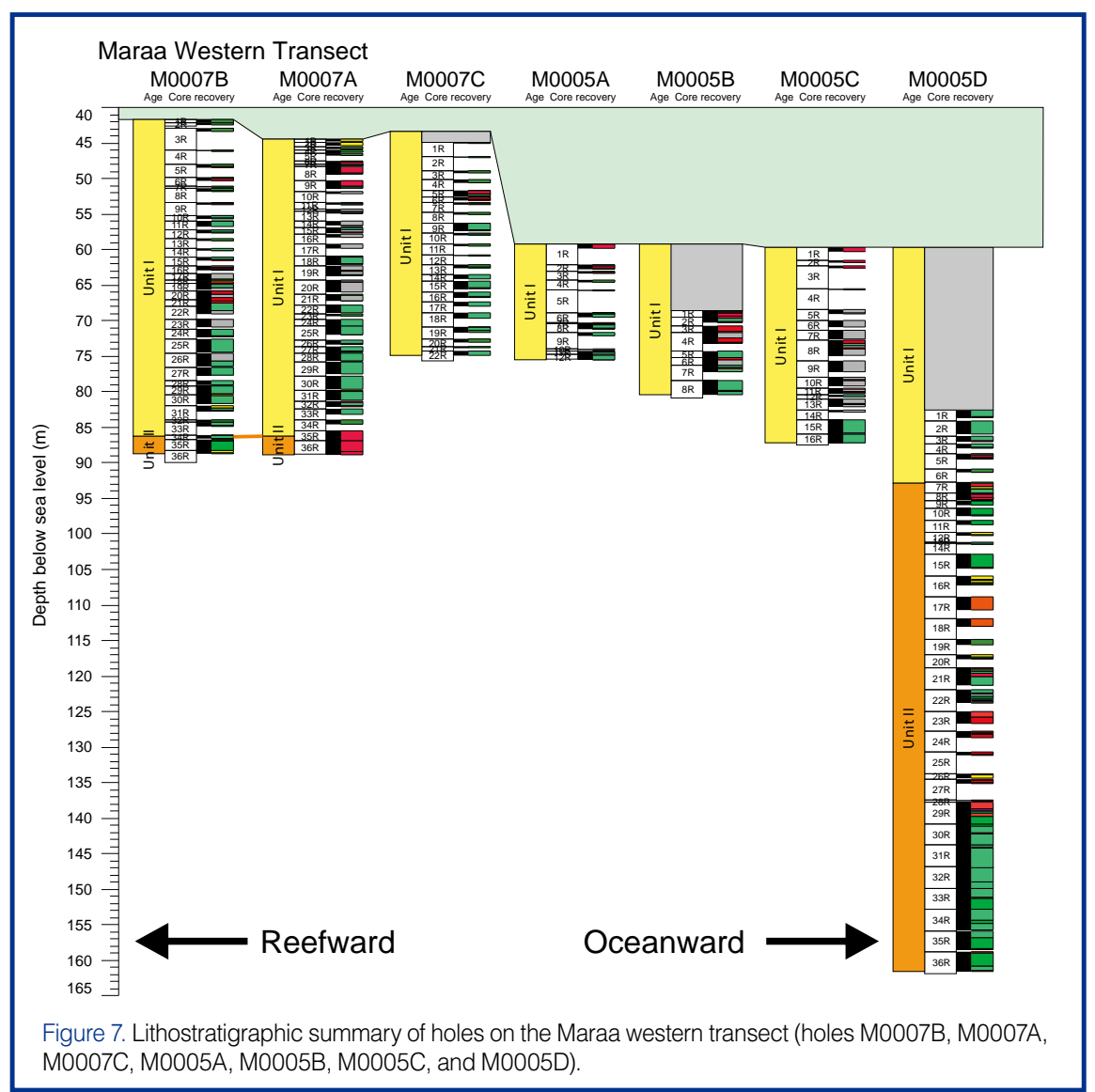

The preliminary dating results indicate that the cored last deglacial sequence should cover at least the $16,000-8,000$ yrs BP time span. Tahiti is therefore the second region, after Barbados, where coral reef records encompass the meltwater pulse events centered at $14,000 \mathrm{yr} \mathrm{BP}$ and 11,300 yr BP (MWP-1A and MWP-1B, respectively). Huge coral colonies, chiefly Porites genus, were found in thirty meters of reef cores; these cores cover successive time windows in most of the 16,000-8,000 years period. The study of those colonies will address interannual/decadal-interdecadal climate variability and seasonality (amplitude and structure) in the south Pacific during the last deglaciation, and will present data that might aid modelling of future global warming. In particular, the high recovery combined with the high resolution downhole measurements provides potential for resolving in unprecedented detail the abrupt and significant environmental changes that accompanied the deglacial sea level rise.

The investigation of the 200 meters of cores retrieved from the older Pleistocene

bound phosphate compounds such as phospholipids or nucleic acids. In contrast, hole M0007B (6.28 mbsf) showed only glucosidase and aminopeptidase activity, which indicates degradation and metabolization of polysaccharides and proteins.

Isolation of microorganisms from biofilm samples was performed on agar plates using a medium that is selective for heterotrophic bacteria. After two weeks incubation time, ten different heterotrophic colonies could be isolated. From experiments intended to locate anaerobes, only one isolate was found. Distinct groups of microorganisms are associated in the biofilm that could range from aerobic to anaerobic. The occurrence of pyrite well distributed in the sediment supports the prevalence of a certain degree of anoxia in the environment.

\section{Concluding Remarks and Future Plans}

The 600 meters of reef cores with a very high recovery ( $>90 \%$ of the carbonates) were retrieved from thirty-seven holes in 40-120 m water depth and situated on transects in three different areas around Tahiti during the IODP Expedition 310. They provided an exceptional and high resolution record of sea level, climatic, and environmental changes during part of the last deglaciation (about $400 \mathrm{~m}$ of cores recovered at 40-122 m below current sea level) and several time windows from the Pleistocene (about $200 \mathrm{~m}$ of cores recovered at 85-160 m below sea level). carbonate sequences might provide fragmentary information on sea level and reef growth for time windows concerning several isotopic stages.

The geomicrobiological pilot study of living biofilms bearing carbonate precipitates that were sampled in situ within cavities underpins a new field of research regarding the development of microbial communities on modern reef slope environments. It will be useful to the nature and environmental significance of microbialite fabrics that form an essential component of the last deglacial reef sequence.

Plans for supplementary drilling operations at four sites offshore the Australian Great Barrier Reef are currently being prepared for possible implementation during 2008-2009.

\section{Acknowledgements}

We would like to thank all the people and institutions including the ODP and IODP scientific advisory structure that helped us to pursue this ambitious and challenging project and make it into a very successful expedition with unprecedented recovery of shallow water carbonate rocks.

The ECORD Science Operator (ESO) and its subcontractors made very strong efforts to make this program happen in the best conditions during all stages from planning and 
drilling through final core description and sampling at the premises of the IODP Bremen Core Repository.

The talented drillers from Seacore Ltd. did an incredible job by delivering exceptional cores, always with humor and grace. We cannot end without mentioning the crew of the $D P$ Hunter and Captain William Roger who made our life very pleasant during the expedition.

\section{IODP Expedition 310 Scientists}

G. Camoin (Co-Chief Scientist), Y. Iryu (Co-Chief Scientist), D. McInroy (Staff Scientist), R. Asami, H. Braaksma, G. Cabioch, P. Castillo, A. Cohen, J.E. Cole, P. Deschamps, R.G. Fairbanks, T. Felis, K. Fujita, E. Hathorne, S. Lund, H. Machiyama, H. Matsuda, T.M. Quinn, K. Sugihara, A. Thomas, C. Vasconcelos, K. Verwer, R. Warthmann, J.M. Webster, H. Westphal, K.S. Woo, T. Yamada, and Y. Yokoyama.

\section{References}

Bard, E., Hamelin, B., and Fairbanks, R.G., 1990. U-Th ages obtained by mass spectrometry in corals from Barbados: sea level during the past 130,000 years. Nature, 346:456-458, doi:10.1038/346456a0.

Bard, E., Hamelin, B., Arnold, M., Montaggioni, L.F., Cabioch, G., Faure, G., and Rougerie, F., 1996. Deglacial sea level record from Tahiti corals and the timing of global meltwater discharge. Nature, 382:241-244, doi:10.1038/382241a0.

Bjerknes, J., 1969. Atmospheric teleconnections from the equatorial Pacific. Mon. Wea. Rev., 97:163-172.

Blanchon, P., and Shaw, J., 1995. Reef drowning during the last deglaciation: evidence for catastrophic sea level rise and ice-sheet collapse. Geology, 23:4-8, doi:10.1130/00917613(1995) 023<0004:RDDTLD >2.3.CO;2.

Cabioch, G., Camoin, G.F., and Montaggioni, L.F., 1999a. Postglacial growth history of a French Polynesian barrier reef (Tahiti, central Pacific). Sedimentology, 46:985-1000, doi:10.1046/ j.1365-3091.1999.00254.x.

Cabioch, G., Montaggioni, L.F., Faure, G., and Ribaud-Laurenti, A., 1999b. Reef coralgal assemblages as recorders of paleobathymetry and sea level changes in the Indo-Pacific province. Quat. Sci. Rev., 18:1681-1695.

Camoin, G.F., and Montaggioni, L.F., 1994. High energy coralgalstromatolite frameworks from Holocene reefs (Tahiti, French Polynesia). Sedimentiol, 41:655-676, doi:10.1111/ j.1365-3091.1994.tb01416.x.

Camoin, G.F., Colonna, M., Montaggioni, L.F., Casanova, J., Faure, G., and Thomassin, B.A., 1997. Holocene sea level changes and reef development in southwestern Indian Ocean. Coral Reefs, 16:247-259.

Camoin, G.F., Gautret, P., Montaggioni, L.F., and Cabioch, G., 1999. Nature and environmental significance of microbialites in Quaternary reefs: the Tahiti paradox. Sediment. Geol., 126:271-304, doi:10.1016/S0037-0738(99)00045-7.

Camoin, G.F., Cabioch, G., Hamelin, B., and Lericolais, G., 2003. Rapport de mission SISMITA. Institut de recherche pour le développement, Papeete, Polynesia Francaise.

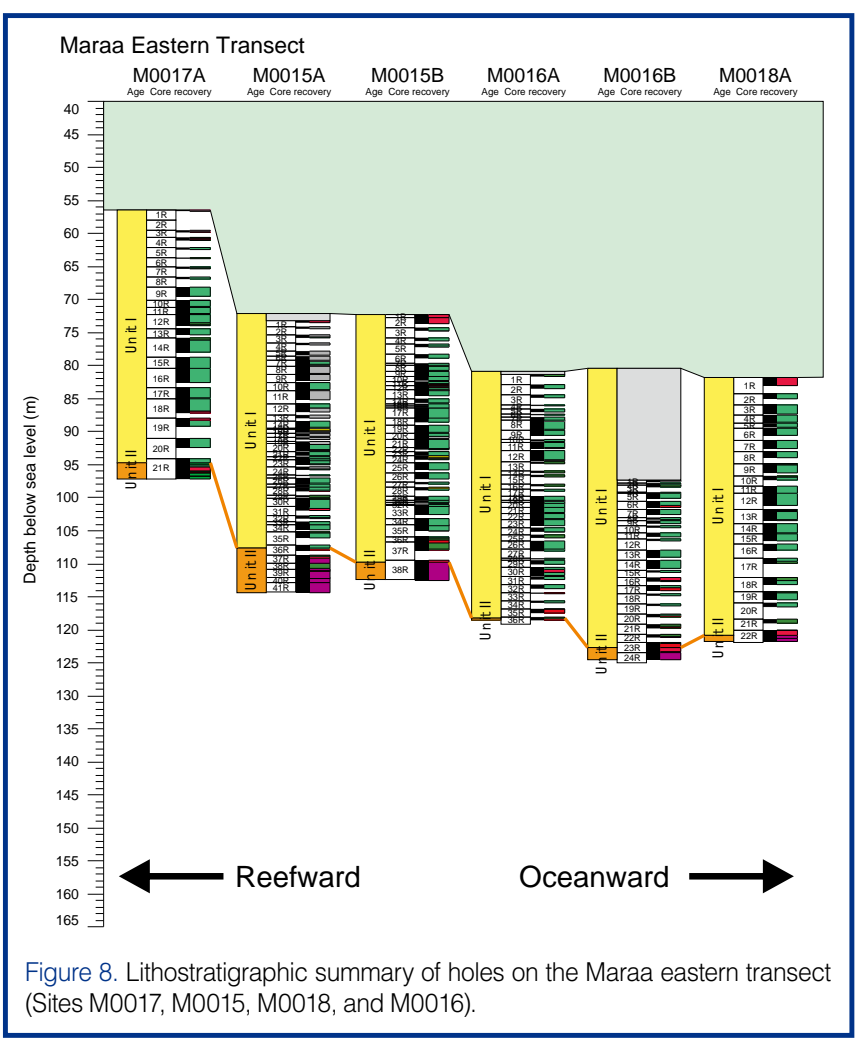

Camoin, G.F., Montaggioni, L.F., and Braithwaite, C.J.R., 2004. Late glacial to postglacial sea levels in the Western Indian Ocean. Mar. Geol., 206:119-146.

Camoin, G.F., Cabioch, G., Eisenhauer, A., Braga, J.C., Hamelin, B., and Lericolais, G., 2006. Environmental significance of microbialites in reef environments during the last deglaciation. Sediment. Geol., 185:277-295, doi:10.1016/j. sedgeo.2005.12.018.

Camoin, G.F., Westphal, H., Séard, C., Heindel, K., Yokoyama, Y., Matsuzaki, M., Vasconcelos, C., Warthmann, R., Webster, J., and IODP Expedition 310 Scientists, 2007. Microbialites: a major component of the last deglacial reef sequence from Tahiti (IODP Expedition \#310). Environmental significance and sedimentological roles. Poster presentation. EGU Conference, Vienna, 15-20 April 2007.

Chappell, J., and Polach, H.A., 1991. Postglacial sea level rise from a coral record at Huon Peninsula, Papua New Guinea. Nature, 349:147-149, doi:10.1016/S0277-3791(01)00118-4.

Clark, P.U., and Mix, A.C., 2002. Ice sheets and the sea level of the Last Glacial Maximum. Quat. Sci. Rev., 21:1-7, doi:10.1016/ S0277-3791(01)00118-4.

Clark, P.U., McCabe, A.M., Mix, A.C., and Weaver, A.J., 2004. Rapid rise of sea level 19,000 years ago and its global implications. Science, 304:1141-1144, doi:10.1126/science.1094449.

Deschamps, P., Durand, N., Bard, E., Hamelin, B., Camoin, G.F., Thomas, A.L., Henderson, G.M., Yokoyama, Y., and IODP Expedition 310 Scientists, 2006. Extending the Tahiti postglacial sea-level record with offshore drilled corals. First results from IODP Expedition 310. SEALAIX International Symposium, Giens, France, 25-29 September 2006.

Deschamps, P., Durand, N., Bard, E., Hamelin, B., Camoin, G.F., Thomas, A.L., Henderson, G.M., Yokoyama, Y., and IODP Expedition 310 Scientists., 2007. New evidence for the exis- 
tence of the MWP-1A from a "far-field" site. Preliminary results from the Tahiti IODP Expedition 310. EGU Conference, Vienna, 15-20 April 2007.

Edwards, R.L., Beck, W.J., Burr, G.S., Donahue, D.J., Chappell, J.M.A., Bloom, A.L., Druffel, E.R.M., and Taylor, F.W., 1993. A large drop in atmospheric $14 \mathrm{C} / 12 \mathrm{C}$ reduced melting in the Younger Dryas, documented with $230 \mathrm{Th}$ ages of corals. Science, 260:962-968, doi:10.1038/342637a0.

Fairbanks, R.G., 1989. A 17,000-year glacio-eustatic sea-level record: Influence of glacial melting rates on the Younger Dryas event and deep-ocean circulation. Nature, 342:637-642.

Felis, T., Asami, R., Deschamps, P., Kölling, M., Durand, N., Bard, E., and IODP Expedition 310 Scientists., 2007. Sub-seasonal reconstructions of South Pacific climate during the last deglaciation from Tahiti corals-Preliminary results from IODP Expedition 310. EGU Conference, Vienna, 15-20 April 2007.

Heindel, K., Westphal, H., Camoin, G.F., Séard, C., Birgel, D., Peckmann, J., and IODP Expedition 310 Scientists, 2007. Microbialite-dominated coral reefs as response to abrupt environmental changes during the last deglacial sea level rise. IODP Expedition \#310, Tahiti. Poster presentation. EGU Conference, Vienna, 15-20 April 2007.

Lambeck, K., 1993. Glacial rebound and sea level change: an example of a relationship between mantle and surface processes. Tectonophysics, 223:15-37, doi: 10.1016/00401951(93)90155-D.

Lambeck, K., Yokoyama, Y., and Purcell, A., 2002. Into and out of the Last Glacial Maximum: sea level change during oxygen isotope stages 3 and 2. Quat. Sci. Rev., 21:343-360, doi:10.1016/S0277-3791(01)00071-3.

Lindstrom, D.R., and MacAyeal, D.R., 1993. Death of an ice sheet. Nature, 365:214-215, doi:10.1038/365214a0.

McKenzie, J., Vasconcelos, C., Warthmann, R., and Camoin, G.F., 2007. Microbialite structures as a component of last deglacial reef sequence in Tahiti drill cores, IODP Expedition 310: initial results from geomicrobiological study. IAS Regional Meeting, Patras, Greece, 4-7 September 2007.

Ménabréaz, L., 2007. Caractérisation des faciès et magnétostratigraphie de la séquence récifale pléistocène de Tahiti (Expedition IODP 310). Rapp. Master 2, Ecole Doctorale Sciences de l'Environnement d'Aix-Marseille (unpublished).

Mix, A., Bard, E., and Schneider, R., 2001. Environmental processes of the ice age: land, oceans, glaciers (EPILOG). Quat. Sci. Rev., 20:627-657, doi:10.1016/S0277-3791(00)00145-1.

Montaggioni, L.F., and Faure, G., 1997. Response of reef coral communities to sea level rise: a Holocene model from Mauritius (Western Indian Ocean). Sedimentol., 44:1053-1070.

Montaggioni, L.F., Cabioch, G., Camoin, G.F., Bard, E., RibaudLaurenti, A., Faure, G., Déjardin, P., and Récy, J., 1997. Continuous record of reef growth over the past 14 k.y. on the mid-Pacific island of Tahiti. Geology, 25:555-558, doi:10.1130/0091-7613(1997)025<0555:CRORGO>2.3.CO;2.

Nakada, M., and Lambeck, K., 1989. Late Pleistocene and Holocene sea level change in the Australian region and mantle rheology. Geophys. J., 96:497-517.

Okuno J., and Nakada, M., 1999. Total volume and temporal variation of meltwater from last glacial maximum inferred from sea level observations at Barbados and Tahiti. Palaeogeogr.
Palaeoclimatol. Palaeoecol., 146:283-293, doi:10.1016/ S0031-0182(98)00136-9.

Peltier, W.R., 1994. Ice age paleotopography. Science, 265 :195-201, doi:10.1126/science.265.5169.195.

Pickard, G.L., and Emery, W.J., 1990. Descriptive Physical Oceanography, 5th Edition, Butterworth-Heinemann (Burlington).

Premoli Silva, I., Haggerty, J., Rack, F., and Shipboard Scientific Party, 1993. Northwest Pacific Atolls and Guyots, Proceed. ODP, Init. Repts., 144. College Station, Texas (Ocean Drilling Program).

Sagawa, N., Nakamori, T. and Iryu, Y., 2001. Pleistocene reef development in the southwest Ryukyu Islands, Japan. Palaeogeogr. Palaeoclimatol. Palaeoecol., 175:303-323.

Sager, W.W., Winterer, E.L., Firth J.V., and Shipboard Scientific Party, 1993. Northwest Pacific Atolls and Guyots, Proceed. ODP, Init. Repts., 143, College Station, Texas (Ocean Drilling Program).

Sugihara, K., Yamada, T., and Iryu, Y., 2006. Contrasts of coral zonation between Ishigaki Island (Japan, northwestern Pacific) and Tahiti Island (French Polynesia, central Pacific), and its significance in Quaternary reef growth histories. SEALAIX International Symposium, Giens, France, 25-29 September 2006.

Thomas, A.L., Henderson, G.M., Deschamps, P., Yokoyama, Y., Bard, E., Durand, N., Hamelin, B., Camoin, G.F., and IODP Expedition 310 Scientists, 2006. Preliminary results from the IODP Expedition 310 "Tahiti Sea Level”: U-Th dating of Pleistocene reef material. SEALAIX International Symposium, Giens, France, 25-29 September 2006.

Yokoyama, Y., De Deckker, P., Lambeck, K., Johnston, P., and Fifield, L.K., 2001. Sea level at the Last Glacial Maximum: evidence from northwestern Australia to constrain ice volumes for oxygen isotope stage 2. Palaeogeogr. Palaeoclimatol. Palaeoecol., 165: 281-297, doi:10.1016/S00310182(00)00164-4.

\section{Authors}

Gilbert F. Camoin, Centre Européen de Recherche et d'Enseignement des Géosciences de l'Environnement (CEREGE) UMR 6635 CNRS, Europôle Méditerranéen de l'Arbois, BP 80, F-13545 Aix-en-Provence cedex 4, France, e-mail: gcamoin@cerege.fr.

Yasufumi Iryu, Institute of Geology and Paleontology, Graduate School of Science, Tohoku University, Aobayama, Sendai 980-8578, Japan, email: iryu@dges.tohoku.ac.jp.

Dave B. McInroy, British Geological Survey, Murchison House, West Mains Road, Edinburgh EH9 3LA, U.K., email: dbm@bgs.ac.uk.

and the IODP Expedition 310 Scientists.

\section{Related Web Links}

http://www.eso.ecord.org/expeditions/310/310.htm http://www.rcom.marum.de/English/Tahiti_Sea-Level_ Expedition_2005.html 